УДК 159.901

DOI https://doi.org/10.32838/2709-3093/2021.3/19

Завгородня О.В.

Інститут психології імені Г.С. Костюка Національної академії педагогічних наук України

\title{
РОЗВИТОК ОБРАЗОТВОРЧОГО МИСЛЕННЯ НА МАТЕРІАЛІ ДИТЯЧОГО МАЛЮВАННЯ
}

У статті розглядається спільне й відмінне у розвитку образотворчого мислення на матеріалі малювання дітей. В ході продукування перших каракулів дитина інтуїтивно відкриває для себе спочатку емочійно-рухову стратегію самовиявлення, а потім - більш ефективну - символічно-образну стратегію. Перехід до иієї форми графічного самовираження знаменує зародження образотворчого мислення. Починають інтенсивно формуватись $i$ функиіонувати всі складники образотворчого мислення. Пізнавально-імпресивний складник, щзо закладається ще на стадії каракулів, готує трунт для образотворення. Фантазійно-перетворювальний складник забезпечує трансформацію емочійно-чуттєвого матеріалу у візуальні форми. Структурно-композииійний складник стосується конструювання композиції твору. Художньо-матеріальний складник передбачає пережсивання тактильних якостей матеріалу, роботи з інструментами, відчуття їх виразної ефективності та обмежень. Образотворче мислення здійснюється в формах матеріалу та техніки, відповідних до типу художнього вираження та творчих намірів дитини. За віковими показниками розвитку малювання дітей існують значні індивідуальні відмінності. Діапазон відмінностей у хлопчиків шириий, ніж у дівчаток. У частини дітей спостерігається прискорений розвиток, ивидка зміна стадій малювання; діти демонструють виражену оригінальність та експресивність створюваних образів, відзначаються яскравою індивідуальністю творчих світів. У розвитку образотворчого мислення дошкільників простежуються такі змістові тенденції: декоративно-структурна; експресивно-психологічна; предметно-просторова. Зачатки иих тенденцій спостерігаються у більшості дітей, але певні з них можуть домінувати. Співвідношення зазначених тенденцій у дошкільному віці є індивідуальними, і иі особливості зберігаються також $і$ в икільному віиі.

Ключові слова: образотворче мислення, індивідуальні відмінності, дитячий малюнок, візуальний досвід, декоративно-структурна тенденџія, графічне самовираження.

Постановка проблеми. Дослідження зародження образотворчого мислення дитини зумовлено тим, що вивчення зазначених процесів дасть змогу, з одного боку, глибше зрозуміти генезу образотворчого мислення, а з іншого - краще осягнути прагнення дитини, як духовної істоти, виявити мотиваційні підстави творчого осмислення нею себе і світу. Наше дослідження продовжує низку розробок з проблематики творчого мислення, зокрема в образотворчій діяльності (2; 3; 4 та ін.). Подальше поглиблення психологічної теорії творчості передбачає вивчення джерел, передумов, початків творчого мислення в ранньому дитячому віці, зокрема різновидів художнього мислення.

Мета дослідження - простежити спільні риси та індивідуальні відмінності розвитку образотворчого мислення у дитини в контексті ії малювання.

Образотворче мислення - різновид художнього мислення, специфікація якого пов' язана з особливостями образотворчого мистецтва; водночас воно $\epsilon$ певною лінією розвитку візуального мислення. Саме в результаті спілкування 3 мистецтвом в обдарованої людини формується особливе (образотворче) мислення, яке полягає в трансформації матеріалу дійсності в образи художнього твору [7]. Образотворче мислення формується на перетині розвитку художнього (в широкому сенсі) та візуального мислення, спрямоване на створення, а також на сприйняття і розуміння творів образотворчого мистецтва.

Феномен дитячого малювання вивчається понад 100 років, а отримані дані та інтерпретації постійно переосмислюються [1; 5; 6; 8 та ін.]. Дитяче малювання - це унікальна пізнавальнотворча діяльність дитини, яка через творчість пізнає, оновлює, вигадує чи заново винаходить у кожному поколінні символічно-образну мову, освоює графічні патерни, опрацьовує їх змістові та формальні аспекти. Малювання - це частина широкої інтерактивної практики самовираження, комунікації, а також смислоутворювальної 
діяльності дітей, в процесі чого, зокрема, розвивається дитяче мислення, насамперед образотворче.

Виклад основного матеріалу дослідження. 3 метою окреслення особливостей зародження й розвитку образотворчого мислення було проаналізовано низку досліджень дитячого малювання $[1 ; 6 ; 8,9]$ в контексті раннього віку [10; 11 та ін.], а також проінтерпретовано наші емпіричні дані (близько 400 малюнків 8 дітей у віковій динаміці від 1,5 років, матеріали бесід з їх матерями, нотатки спостережень щодо процесу малювання, поведінки, вербального супроводу).

Аналіз даних показав, що попри значні індивідуальні відмінності (ранній-пізній розвиток, стрімкий-загальмований, рознобічний-однобічний), в розвитку образотворчої діяльності дітей $\epsilon$ спільні риси. Спочатку діти малюють хаотичні лінії, карлючки, лінії, що закручуються в клубок. Поступово виокремлюються округлі фігури, ритмічні повторення ліній, складніші фігури, схожі на солярні знаки та мандали. 3'являються перші зображення «головоногів» - людей і тварин. Надалі розширюється діапазон зображень - як у дівчаток, так і у хлопчиків - діти малюють дерева, будинки, машини. Часто спостерігаються мотиви спіралі, а також зображення чоловічка в замкненому округлому просторі. Аналіз даних свідчить, що дитячий малюнок - це початково зображеннязнак, тобто певне позначення реального об'єкта; в подальшому - частково - знак, частково - образ, за низкою характеристик подібний до реального об'єкта.

Перші каракулі з'являються на другому році життя дитини в контексті іiі експресивної рухової активності. Дитина «переносить» дії своєї руки на папір, і виникає слід, лінія. Освоєні дітьми рухи-жести (зокрема, приваблювання й відштовхування) знаходять виявлення в створюваних каракулях (як своєрідного продовження жесту руки) [6]. 3 їх допомогою діти досліджують значущі для них реальні й уявні події. Увагу привертають динамічні вияви об'єктів у ситуації взаємодії: наприклад, для дитини собака - привітна, радісно стрибає, може лизнути, собаку можна погладити, або гарчить - треба триматися подалі. Дитина 3 цікавістю розглядає пропоновані дорослим картинки, імітує дорослого - «читає», «пише», вчиться використанню графічних інструментів, освоює «карлючки» і з великим задоволенням заповнює ними весь можливий паперовий простір, а також взаємодіє з дорослим в контексті «інтерпретації» своїх творів, асоціювання карлючок зі своїм досвідом. Маніпулюючи олівцем, діти не просто набувають навичок графічного від-

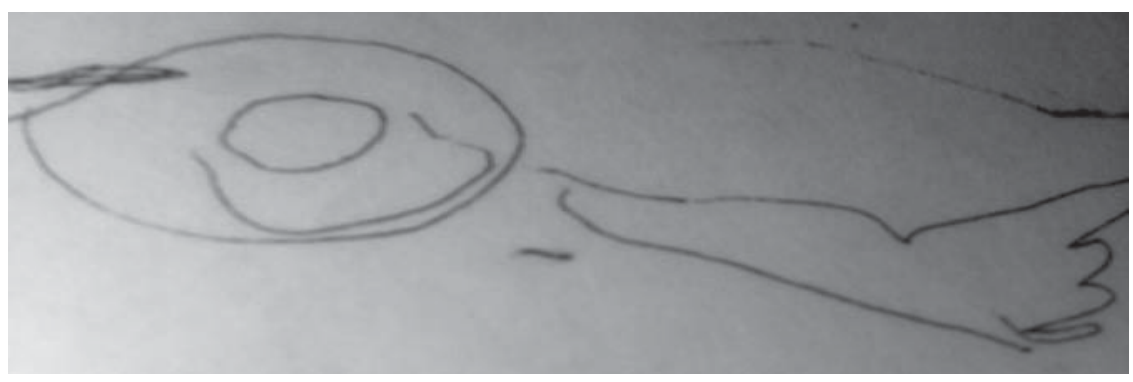

Рис. 1. Іграшки

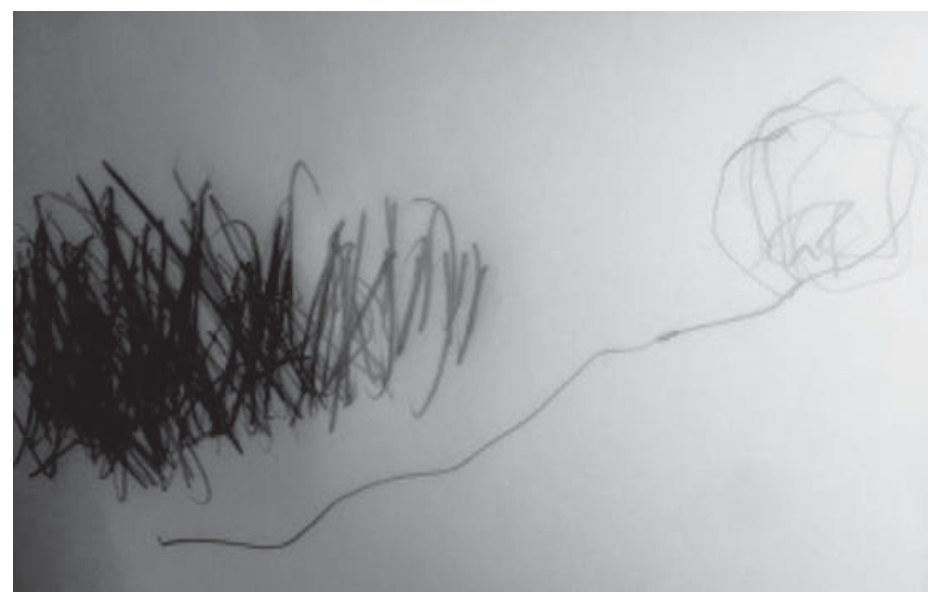

Рис. 2. «Катя і мама біжать додому від грози» 
творення ліній різних типів, а й виражають свій досвід взаємодії з оточенням, у процесі чого спонтанно виробляють своєрідну «мову», елементами якої є лінії та їх поєднання [1]. Використовуються виразні можливості різних ліній як своєрідних графічних патернів, що в подальшому з ускладненням діяльності модифікуються, комбінуються, реконструюються тощо залежно від внутрішньої потреби графічного висловлення дитини.

За спостереженнями мами Каті С. (2 м 1 місяць): Катя малювала іграшки, 3 якими вона грається у пісочній коробці (рис. 1). Переважають круглі, м’які лінії. Інші лінії - на малюнку «Катя і мама біжать додому від грози» (рис. 2).

Передувала малюнку історія 3 грозою. Коли Катя з мамою поверталися додому, почалася гроза. Грім налякав дитину. Невдовзі Катя намалювала гнучку довгу лінію, яка веде від великого жорсткого каракуля «гроза»- 3 важких, загострених і ламаних ліній - до округлого каракулю («будинок»). Каракуль «будинок» сильно відрізняється від каракуля «гроза» і за типом ліній схожий на «улюблені іграшки».

В ході продукування перших каракулів дитина інтуїтивно відкриває (або винаходить) для себе емоційно-рухову стратегію графічного самовиявлення і створює новий (графічний) канал комунікації із значущим оточенням. Каракулі стають інструментом, який оживлює досвід і фантазії дитини. Їх творення здійснюється інтуїтивно, за принципом спонтанних дій, спроб / помилок, за суб'єктивним орієнтиром. Водночас використовується принцип аналогії - наприклад, швидкий рух олівцем по аркуші паперу як аналог швидкого бігу людини. Реалізація емоційно-рухової графічної стратегії, попри свою експресивність, має своїм недоліком те, що ії продукти малозрозумілі для глядача. Комунікативна потреба дитини, а також збагачення іiї візуального досвіду сприяють відкриттю та застосуванню нею ефективнішої стратегії - символічно-образної, яка, зокрема, сприяє розумінню малюнків глядачем. Перехід до цієї форми графічного самовираження знаменує зародження образотворчого мислення. Починають інтенсивно формуватись і функціонувати всі складники образотворчого мислення. Пізнавально-імпресивний складник, що закладається ще на стадії каракулів, готує грунт для образотворення; пов'язаний з пізнавальною активністю, чутливістю, сприйнятливістю, передбачає емпатійне вчування, накопичення «матеріалу» переживань, вражень, а також постійне збагачення візуального досвіду. Фантазійно-перетворювальний складник забезпечує трансформацію емоційночуттєвого матеріалу у візуальні форми, використання стратегій та тактик образотворення з метою міжмодальних та інтрамодальних перетворень. Структурно-композиційний складник стосується конструювання композиції твору, освоєння експресивних можливостей елементів художньої мови, а також мисленнєвих операцій, спрямованих на вибір варіантів форми, композиції тощо. Художньо-матеріальний складник образотворчого мислення передбачає переживання тактильних якостей матеріалу, роботи 3 інструментами, відчуття їх виразної ефективності та обмежень. Образотворче мислення відбувається в формах матеріалу та техніки, відповідних до типу художнього вираження та творчих намірів дитини.

За віковими показниками розвитку малювання дітей існують значні індивідуальні відмінності. Зокрема, в нашому дослідженні поява першого «головонога» у різних дітей спостерігалась у віці від 1 р. 9 міс. до 4 р. 5 міс. Дівчатка за цим показником випереджали хлопчиків. Середній вік появи «головоногів» у дівчаток 2 p. 10 міс., у хлопчиків - 3 p. 11 міс. Діапазон відмінностей у хлопчиків більший, ніж у дівчаток.

$\mathrm{y}$ частини дітей розвиток початкових форм образотворчого мислення був уповільненим впродовж всього дошкільного періоду, показники емоційної експресії та оригінальності графічних продуктів за оцінками експертів були низькими. Як приклад можна розглянути розвиток образотворчої діяльності Данила М. У хлопчика період хаотичних ліній, карлючок, заплутаних у клубок продовжується до 4,5 років. Потім спостерігається певне упорядкування графічної активності - ритмічне повторення ліній, зображення кола, деякий, хоч і слабкий, вияв декоративно-структурної тенденції. Перші антропоморфні зображення (типу «головоногів») з'являються після 5 років, але тема людини не знаходить розвитку. В подальшому в малюнках іноді з'являються схематичні чоловічки як атрибут транспорту (в машині). В 6-7 років хлопчик малює схеми машин, електровозів, роботів, руху місяця навколо землі та інше. Особливий інтерес викликають цифри, які Данилко малює 3 ентузіазмом, надаючи своєрідності кожній з них. Від раннього дитинства простежуються спіралевидні мотиви (від клубка хаотичних ліній до спіралі в 6-7 років, яка позначається як лабіринт). У 8-11 років створює площинні та тривимірні схеми різних механізмів з позначенням розмірів, карту фантастичної країни тощо. Тобто Данилко демонструє певний розвиток візуального мис- 
лення, але не в напряму художнього, образотворчого. Візуальне мислення успішно використовується для тривимірного моделювання предметів, малювання карт, схем; водночас завдання зі створення графічних репрезентацій емоцій викликає труднощі.

Навпаки у частини дітей спостерігається прискорений розвиток, швидка зміна стадій малювання; діти демонструють виражену оригінальність та експресивність створюваних образів, також відзначаються яскравою індивідуальністю образотворення, унікальністю творчих світів.

Зокрема, в розвитку образотворчого мислення здібних дітей простежуються такі тенденції:

- декоративно-структурна (малювання ліній та фігур, що ритмічно повторюються, спроби орнаменталізації, складні декоративні композиціi);

- експресивно-психологічна (малювання емоційно-виразних «головоногів»- людей, антропоморфних тварин, зображення людей у взаємодії, відображення стосунків між ними, створення портретів та автопортретів);

- предметно-просторова (більш-менш реалістичні зображення предметів довкілля, тварин, дерев, будинків, техніки, а також - натюрморти, ландшафтні композиції, різноманітні багатофігурні пейзажі).

Наведемо приклад переваги предметно-просторової тенденції. Михась С. малювати почав рано, перший «головоніг під назвою «котик» з'являється в 2 р. 7 міс. В цей же період малює «головоногів, означених як люди («Я і бабуся» та ін.), після 3 1/2 років зображення людей зникають, хлопчик віддає перевагу зображенню тварин, будинків, дерев, машин. В 3-4 роки у Михася. яскраво виявляється декоративна тенденція («Дельфіни вистрибують із води»), але потім іде на спад. 3 3-4 років в образотворчій діяльності хлопчика починає домінувати предметно-просторова тенденція, прагнення відобразити навколишній світ у всій його багатоманітності, хлопчик малює сільські, міські та фантастичні пейзажі, робить спроби малювання з натури, стилізовано і водночас реалістично зображує тварин, пташок. В 6-7 років малює оригінальні моделі машин, пейзажі зі складною архітектурою та технікою.

Яскраво виявляє індивідуальність, власне бачення, індивідуальні преференції тем, предметів, виразних засобів. Як жанр домінує пейзаж.

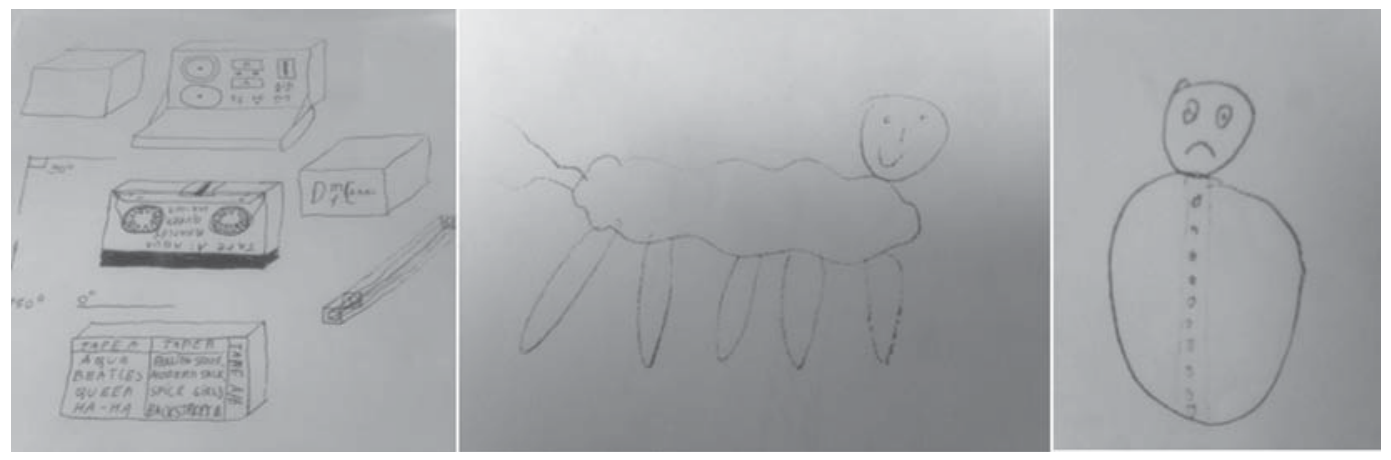

Рис. 3. Малюнки 11 річного Данила М. Успішно моделює тривимірні предмети; водночас завдання намалювати веселу й сумну істоту виконується не без труднощів

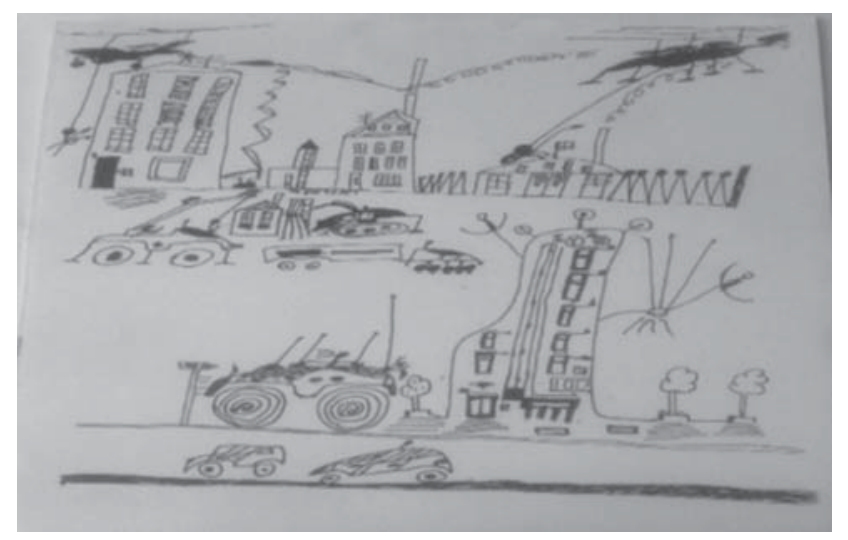

Рис. 4. Урбаністичний пейзаж Михася С. (6 р.) 
Перевага декоративно-структурної тенденції виявилась у Маринки Ч. Дівчинка з 2,5 років малює різні подібні до мандал зображення, різновиди солярних знаків. Перший «головоніг» з'являється в 2 р. 8 міс. Тема чоловічків має значний розвиток. Також малює тварин, квіти, дерева. При цьому зображення мають виражено декоративний характер. Характерні ритмічні повторення елементів образів, орнаменталізація тощо. Добре відчуває колір та його декоративні можливості. На кожному віковому етапі домінування декоративно-структурної тенденції зберігається, але виявляється по-новому. У підлітковому віці малює складні декоративні композиції.

Прикладом переваги експресивно-психологічної тенденції може бути розвиток образотворчої діяльності Лариси Ч. Дівчинка малювати почала рано - близько 1,5 років. Перший головоніг з'являється в 1 р. 9 міс., гуманітарна тема стрімко розвивається. Дівчинка любить зображувати маму 3 дочкою, інших членів родини. 32 років спосте- рігається досить виразна декоративно-структурна тенденція, особливо в серії стилізованих тварин, в оформленні одягу персонажів, зображення сонця тощо. Але найбільш яскравий розвиток знаходить експресивно-психологічна тенденція. Дівчинка в своїх малюнках відображає складні стосунки між людьми, створює портрети та автопортрети, що відзначаються значним психологізмом («Дівчина 3 котом», «Автопортрет» та ін., намальовані в 6-7 років).

Дослідження засвідчило, що зачатки декоративно-структурної, експресивно-психологічної та предметно-просторової тенденцій спостерігаються у більшості здібних дітей, але певні з них можуть домінувати. Співвідношення зазначених тенденцій у дошкільному віці є індивідуальними, і ці особливості зберігаються також і в більш старшому віці.

На межі підліткового віку можна виокремити такі характеристики форм візуального мислення й рівні в контексті перспектив образотворення:

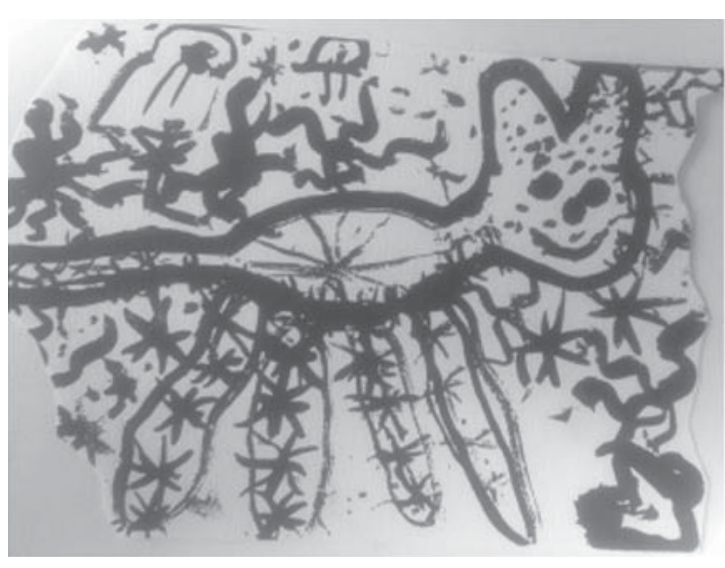

A)

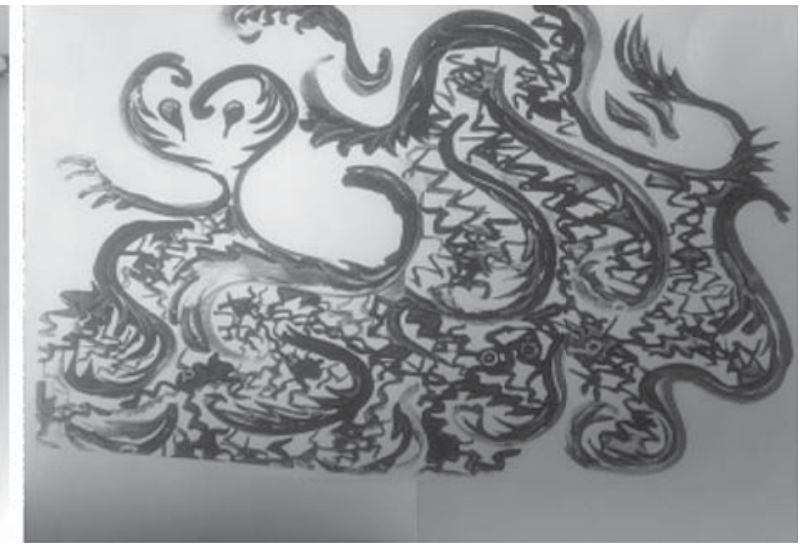

Б)

Рис. 5. А) «Киця», намальована Маринкою у 5 р.; Б) Декоративна композиція, створена в 13 р.

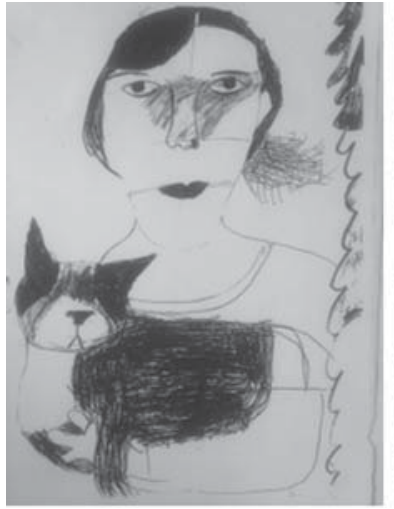

A)

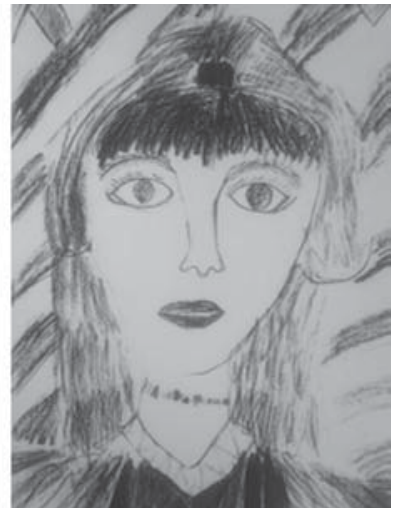

Б)

Рис. 6. Малюнки Лариси Ч. (6 р):

А) «Портрет дівчини 3 котом»; Б) «Автопортрет» 
низький (знаково-схематичний, змістовно-спрощений), середній (наслідувально-ілюстративний), перспективний (індивідуалізований, експресивний, метафоричний) [2].

Підсумовуючи ці дослідження, можна стверджувати, що продуктом первинних форм образотворчого мислення $є$ емоційно-виразний малюнок дитини, в якому доступними їй засобами (через суттєві для неї ознаки суб'єктів та об'єктів довкілля) втілено її почуття, оцінки, ставлення до тих чи інших фрагментів реальності, тобто вираження дитиною в малюнку свого внутрішнього духовного світу, яке може здійснюватися в нефігуративній, перехідній або у фігуративній формі.

Проте чи можна за малюнками дитини передбачити iї досягнення у зрілому віці? 3 метою визначитись в цьому питанні Д. Парізер [9] запропонував експертам дитячі малюнки Пікассо, Клеє та Тулуз-Лотрека поряд з малюнками дітей відповідного віку. Дослідження показали, що в дитячій творчості цих митців виявлялись загальні вікові закономірності. Вчені дійшли висновку, що дитячі малюнки можуть свідчити про відносну обдарованість їх авторів, але не дають змогу передбачити їх майбутні досягнення.

На новому рівні образотворче мислення виявляється, коли підліткову кризу подолано, і молода людина усвідомлює свої творчі прагнення та здібності. Але вищі досягнення митця переважно пов'язані зі зрілими формами образотворчого мислення. На думку А. Мальро, «художник ймовірно володіє оком, але не в п'ятнадцять років... Суверенний спосіб бачення великих художників - це спосіб бачення останніх картин Ренуара, Тиціана, Франса Гальса. Він подібний до голосу глухого Бетховена, це бачення, що зберігається в них, коли вони починають сліпнути» [7, с. 125].

Висновки. Дослідження дало змогу простежити особливості розвитку первинних форм образотворчого мислення в процесі дитячого малювання. Комунікативна потреба дитини, а також збагачення іiї візуального досвіду сприяють відкриттю та застосуванню нею символічно-образної стратегії. Перехід до цієї форми графічного самовираження знаменує зародження образотворчого мислення. Починають інтенсивно формуватись і функціонувати всі складники образотворчого мислення. За віковими показниками розвитку малювання та змістовими характеристиками образотворчого мислення дітей спостерігаються значні індивідуальні відмінності. Зокрема, в індивідуальному розвитку образотворчого мислення дошкільників простежується різне співвідношення та вираженість декоративно-структурної, експресивнопсихологічної, предметно-просторової тендениій. Зачатки изих тенденцій спостерігаються y більшості дітей, але у різних випадках одна з них може домінувати. Проблема психологічних умов розвитку образотворчого мислення здібних дітей у процесі їх дорослішання, досягнення рівня повноцінного функціонування образотворчого мислення в дорослому віці $є$ досі недостатньо вивченою, що може розглядатися як перспектива дослідження.

\section{Список літератури:}

1. Жуковский В.И., Пивоваров Л.В. Зримая сущность. Визуальное мышление в изобразительном искусстве. Свердловск : Изд-во Урал. Ун-та, 1991. 284 с.

2. Завгородняя Е.В. Об опыте изучения роли символических сновидений в художественном творчестве учащихся. Психологическая наука и образование. 1997. № 3. С. 99-103.

3. Медведева Н.В. Теорія архетипів К.Г. Юнга та дослідження творчого сприймання. Simbolic and archetypic in culture and social relations: materials of the IV international scientific conference on March 5-6, 2014. Prague, 2014. C. 21-30.

4. Моляко В.А. Художественная одаренность. Обдарована дитина.1998. № 5-6. С. 10-12.

5. Шміт Ф. Психологія малювання для педагогів. Київ: Державне видавництво. 1921. 115 с.

6. Longobardi C., Quaglia R. and Iotti N.O. Reconsidering the scribbling stage of drawing: a new perspective on toddlers' representational processes. Front. Psychol. 2015. 6:1227. doi: 10.3389/fpsyg.2015.01227

7. Malraux A. Psychologie de l'Art: La création artistique. Paris: édit. A. Skira. 1948. 226 p.

8. Papandreou, M. Communicating and thinking through drawing activity in early childhood. J. Res. Child. Educ. 2014. 28, 85-100. doi: 10.1080/02568543.2013.851131

9. Pariser D. The juvenile drawing of Klee, Toulaus-Lautrec and Picasso. Visual arts' research. 1987. N 2. P. 53-67.

10. Piaget, J. The Child's Conception of the World. New York: Harcourt, Brace \& World. 1967. 258 p.

11. Pinto, G., Gamanossi, B. A., and Cameron, C. A. From scribbles to meanings: social interactions in different cultures and emergence of young children's early urdrawing. Early Child Dev. Care. 2011. 181, 425-444. doi: $10.1080 / 03004430903442001$. 


\section{Zavhorodnia O.V. DEVELOPMENT OF FINE-ART THINKING \\ ON THE MATERIAL OF CHILDREN'S DRAWING}

The article considers a common and different in the development of fine-art thinking on the material of children's drawing. During the production of the uring the production of the scribbles, the child intuitively discovers first the emotional-motor strategy and later discovers, the child intuitively discovers first the emotional-motor strategy of graphic self-expression and later discovers a more effective strategy - symbolic-figurative. The transition to this form of graphic self-expression marks the emergence of fine-art thinking. All components of fine-art thinking begin to form and function intensively. The cognitive-impressive component, which is laid at the stage of doodles, prepares the ground for formation. The fantasy-transforming component provides the transformation of emotional and sensory material into visual forms. The structural-compositional component concerns the construction of the composition of the work. The artistic-material component of fine-art thinking involves experiencing the tactile qualities of the material, working with tools, a sense of their expressive effectiveness and limitations. Fine-art thinking takes place in the forms of material and technique, corresponding to the type of artistic expression and creative intentions of the child. There are significant individual differences in the age indicators of children's drawing development. The range of differences in boys is wider than in girls. In some children there is an accelerated development, rapid change of stages of drawing; children demonstrate the expressed originality and expressiveness of the created images, also are noted by bright individuality of creative worlds. The following tendencies can be traced in the development of fine-art thinking of preschoolers: decorative-structural; expressive-psychological; subject-spatial. The primary forms of these trends are observed in most children, but some of them may dominate. The ratio of these trends in preschool age is individual, and these features persist in school age.

Key words: fine-art thinking, individual differences, children's drawing, visual experience, decorative-structural trend, graphic self-expression. 